\title{
Chitinozoans and the age of the Soom Shale, an Ordovician black shale Lagerstätte, South Africa
}

\author{
THIJS R. A. VANDENBROUCKE ${ }^{1,3, *}$, SARAH E. GABBOTT ${ }^{1}$, FLORENTIN PARIS $^{2}$, RICHARD J. ALDRIDGE ${ }^{1} \&$ \\ JOHANNES N. THERON ${ }^{4}$ \\ ${ }^{1}$ Department of Geology, University of Leicester, University Road, Leicester LE1 7RH, UK \\ ${ }^{2}$ Université de Rennes, Géosciences-Rennes, UMR 6118 du CNRS, Campus de Beaulieu, 35042 Rennes-cedex, France \\ ${ }^{3}$ Current address: Research Unit Palaeontology, Ghent University WE13, Krijgslaan 281/S 8, 9000 Ghent, Belgium \\ ${ }^{4}$ Department of Geology, University of Stellenbosch, Private Bag XI, Stellenbosch 7602, South Africa \\ ${ }^{*}$ Corresponding author (e-mail: Thijs.vandenbroucke@UGent.be)
}

\begin{abstract}
Isolated chitinozoans from the Soom Shale Member of the Cedarberg Formation, SW South Africa are described and provide a date of the latest Hirnantian-earliest Rhuddanian. The recovered chitinozoans are typical of the latest Ordovician Spinachitina oulebsiri Biozone, although an earliest Silurian age is possible. They indicate a very short time span (less than $1 \mathrm{Ma}$ ) across the Ordovician-Silurian boundary. This is currently the highest biostratigraphical resolution attainable for the Soom Shale Lagerstätte. Correlation of the Soom Shale chitinozoans with identical assemblages in post-glacial, transgressive deposits of Northern Africa is possible; both faunas occur in shales that overlie glacial diamictites of the Hirnantian glaciation. A new species, Spinachitina verniersi n. sp. is described. J. Micropalaeontol. 28(1): 53-66, May 2009.
\end{abstract}

KEYWORDS: Hirnantian, chitinozoans, Soom Shale, Lagerstätte, Ordovician-Silurian boundary

\section{INTRODUCTION}

Location, sedimentology and importance of the Soom Shale The Soom Shale Member and the overlying Disa Siltstone Member comprise the Cedarberg Formation of the Table Mountain Group, which crops out in the Cape Province of South Africa. Importantly, both members of the Cedarberg Formation contain the only dateable fossils known in the whole Table Mountain Group, a sequence of sediments of latest Cambrian to Early Devonian age. The Soom Shale Member is a parallel-laminated black shale, reported to contain dropstones (Rust, 1981; Hiller, 1992), which overlies, with a gradational contact, the glaciogenic diamict of the Pakhuis Formation. Thus, it is thought to represent deposition of sediment close to a retreating ice front in a quiet water basin (Theron \& Thamm, 1990). None of the fossils show signs of having been transported from outside of this basin (Gabbott, 1998).

The Soom Shale Member is famous as it hosts exceptionally well-preserved fossils, including the soft part remains of conodonts (Aldridge \& Theron, 1993; Gabbott et al., 1995), many arthropod groups (e.g. Braddy et al., 1995, 1999; Gabbott et al., 2003; Whittle et al., 2007) and enigmatic taxa (Aldridge et al., 2001), as well as a shelly fauna dominated by brachiopods, but most notably including orthocones with well-preserved radulae (Gabbott, 1999).

Before this investigation, the age of the Soom Shale was not very precisely known (see discussion below). This was unfortunate, not only because its important well-preserved fauna was loosely constrained in time, but also because of the potentially important role it could play in providing new insights on the post-glacial melting and climatic amelioration scenario following the Hirnantian glaciation. For example, Page et al. (2007) suggested that de-glacial, anoxic, transgressive black shales may have acted as significant carbon sinks, producing a negative feedback mechanism for climatic warming and aiding stabilization of the Early Palaeozoic Icehouse (EPI) conditions. They cited the Soom Shale as a potential candidate for such a carbon sink and we can now confirm that its age is consistent with this and thus it may have played a role in climatic transition (Page et al., 2007, p. 133).

\section{The age of the Cedarberg Formation and the Soom Shale Member}

Cocks \& Fortey (1986) provided an overview of dating of the Cedarberg Formation. In summary, the Soom Shale Member has yielded the trilobite Mucronaspis olini, which is indicative of a latest Ordovician age (Rawtheyan-Hirnantian), i.e. late Katian-Hirnantian according to the new international timescale (Bergström et al., 2006). The overlying Disa Siltstone Member contains a shelly fauna that Cocks \& Fortey (1986, p. 440) considered to have an overall generic aspect similar to that of the Hirnantia fauna, which is widespread in the latest Ordovician. However, other authors, such as Berry \& Boucot (1973), have attributed the same fauna to the earliest Silurian (see overview in Cocks \& Fortey, 1986). Gray et al. (1986) used the size of spore tetrads to suggest a Llandovery age, although they could not rule out a latest Ordovician age. Meanwhile, Rong \& Harper (1988, p. 388), in considering the Disa Siltstone brachiopods, argued that 'the Cedarberg fauna is not a typical member of the Hirnantia fauna but, nonetheless, may be a related assemblage of Hirnantian age'. In addition, Rong et al. (2002) have shown that the Hirnantia fauna is diachronous, ranging from the Katian (Rawtheyan) to the Rhuddanian.

In this paper, our aims are to describe and illustrate new chitinozoans from the Soom Shale Member that are age diagnostic. These fossils, for the first time, enable us to make high-resolution correlations with more precisely constrained sections elsewhere.

\section{SOOM SHALE CHITINOZOANS}

\section{Previous chitinozoan work}

Chitinozoans have been previously recovered from three localities from the Soom Shale Member (Fig. 1). Isolated chitinozoans 

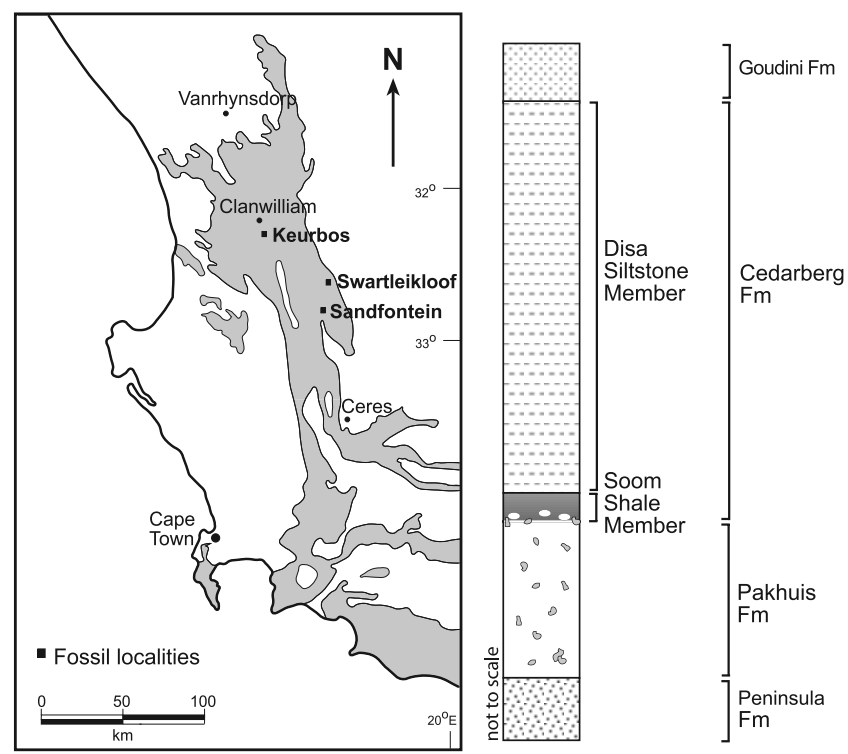

Fig. 1. Map of part of the Western Cape Province, South Africa showing the outcrop area of the Table Mountain Group (shaded grey) and the fossil-collecting localities Keurbos, Swartleikloof and Sandfontein. The core ('Keurbos 70') from which the chitinozoan samples were taken is located $1 \mathrm{~km}$ southwest of the main Keurbos locality. Alongside is a schematic stratigraphical section showing part of the Table Mountain Group and the position of the Soom Shale Member which has dropstones at its base. The exact depths of sample collection in the core are given in Table 1.

were first described from this unit at the Swartleikloof locality by Cramer et al. (1974), who listed a fauna consisting mainly of species of the genera Ancyrochitina, Conochitina, Cyathochitina and Desmochitina. The fauna, as listed by these authors, is not highly age diagnostic and they were only able to date the deposit to the 'Upper Ordovician'. No systematic descriptions were provided and no scanning electron microscope (SEM) photographs were shown, so we cannot make detailed comparisons between their material and the collections we have studied.
Chitinozoans from two other localities, Keurbos and Sandfontein (Fig. 1) were described and illustrated by Gabbott et al. (1998). Their specimens, mainly of the genus Cyathochitina, occurred on bedding planes as scattered individuals, linked chains and aggregated masses, sometimes associated with organic envelopes. These chitinozoans are conspicuous on freshly split bedding planes preserved as organic remains, clay mineral films or composites of both these preservation modes (Gabbott, 1998; Gabbott et al., 2001).

\section{Material and methods}

In this study, core material (in ascending order samples K2.0, $\mathrm{K} 2.3, \mathrm{~K} 2.9 \alpha, \mathrm{K} 2.10, \mathrm{~K} 2.14$ and K 2.14A) from the 'Keurbos 70' borehole approximately $1 \mathrm{~km}$ southwest of Keurbos (see Fig. 1) was examined, and the samples yielded moderately wellpreserved chitinozoans. The core sediment is black and relatively fresh when compared to the quarry site at Keurbos where the sediment is grey. In addition, one sample described herein (S4) comes from Swartleikloof. Here small exposures of Soom Shale can be found in the base of a stream bed, where the shale is very black and contains fresh pyrite. The samples were treated using standard palynological techniques (Paris, 1981). In addition, the residues, which were very rich in organic matter, were treated with standard household bleach $(\mathrm{NaOCl})$ in order to facilitate chitinozoan hand picking. Comparison of bleached and unbleached specimens from the same sample showed that the bleaching technique did not notably change the appearance or state of preservation of the chitinozoan specimens. All studied (and illustrated) specimens are stored at the Council for Geoscience, Bellville, South Africa.

\section{CHITINOZOAN RESULTS}

Several of the samples studied yielded moderately well-preserved chitinozoans, listed in Table 1. The dominant species belong to the genera Ancyrochitina, Spinachitina and Cyathochitina. The specimens of the latter genus belong to the Cyathochitina caputoi group, and are morphologically closest to the chitinozoans

\begin{tabular}{|c|c|c|c|c|c|c|c|}
\hline $\begin{array}{l}\text { Chitinozoan identifications } \\
\text { Depth in core }(\mathrm{m})\end{array}$ & $\begin{array}{c}\text { S4 } \\
*\end{array}$ & $\begin{array}{l}\text { K } 2.0 \\
23.65\end{array}$ & $\begin{array}{l}\text { K } 2.3 \\
21.44\end{array}$ & $\begin{array}{l}\mathrm{K} 2.9 \alpha \\
15.45\end{array}$ & $\begin{array}{c}\text { K } 2.10 \\
14.45\end{array}$ & $\begin{array}{c}\mathrm{K} 2.14 \mathrm{~A} \\
12.05\end{array}$ & $\begin{array}{c}\text { K } 2.14 \\
12.00\end{array}$ \\
\hline Ancyrochitina sp. A & - & 65 & - & - & - & - & - \\
\hline Ancyrochitina sp. B & - & 320 & 62 & 7 & - & - & - \\
\hline Ancyrochitina sp. C & - & 53 & - & 1 & - & - & - \\
\hline Ancyrochitina spp. & - & 43 & 5 & 1 & 5 & - & - \\
\hline Angochitina spp. & - & 5 & 4 & - & - & - & - \\
\hline Spinachitina oulebsiri & - & 103 & - & - & 2 & - & - \\
\hline Spinachitina verniersi $\mathrm{n} . \mathrm{sp}$. & - & 57 & - & 1 & - & - & - \\
\hline Spinachitina spp. & - & 15 & - & - & - & - & - \\
\hline Fungochitina sp. & - & - & - & 1 & - & - & - \\
\hline Cyathochitina caputoi Group & - & - & - & 6 & 72 & 4 & - \\
\hline Lagenochitina sp. & - & - & - & - & 1 & - & - \\
\hline Chitinozoa indet. & - & 25 & 2 & 3 & - & - & - \\
\hline scolecodont & - & - & $\mathrm{x}$ & 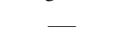 & - & - & - \\
\hline Total number of chitinozoans & 0 & 686 & 73 & 20 & 80 & 4 & 0 \\
\hline Sample size $(\mathrm{g})$ & 35.44 & 10.75 & 23.44 & 10.24 & 14.31 & 12.19 & 13.08 \\
\hline
\end{tabular}

The top of the diamictite of the Pakhuis Formation in the core is observed at $23.82 \mathrm{~m}$.

Table 1. Chitinozoan results from samples from the 'Keurbos 70' core approximately $1 \mathrm{~km}$ southwest of Keurbos, except sample S4 (*), which was collected in Swartleikloof. 


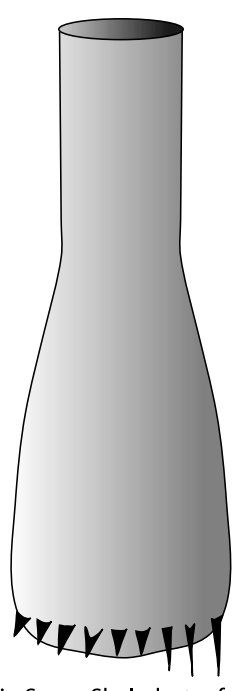

Not found in Soom Shale, but referred to as Spinachitina fragilis (long forms or sensu Paris)

Spinachitina fragilis

Spinachitina fragilis

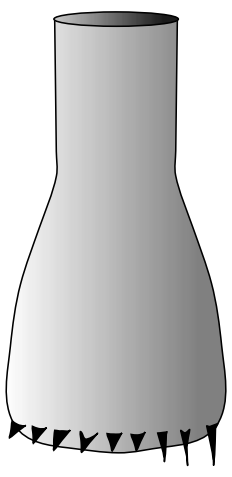

Spinachitina oulebsiri

Spinachitina fragilis

Spinachitina oulebsiri

latest Ordovician - earliest Silurian

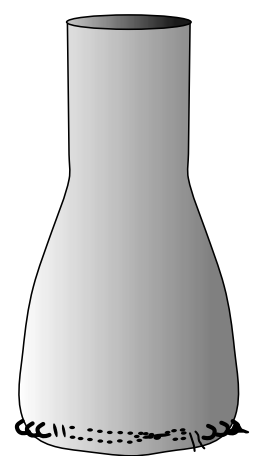

Spinachitina verniersi $\mathrm{n} . \mathrm{sp}$

Herein

Spinachitina fragilis

Spinachitina sp. aff oulebsiri

(Butcher, 2009)

(Paris et al., 2000)

Silurian

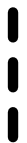

latest Ordovician - earliest Silurian?

Fig. 2. A suite of three distinct but morphologically very similar Spinachitina species that range around the Ordovician-Silurian boundary in the N. Gondwanan realm and a summary of their recent taxonomic history.

described from bedding planes by Gabbott et al. (1998: 449, figs $2 \mathrm{a}, \mathrm{b})$. Spinachitina oulebsiri and Spinachitina verniersi $\mathrm{n}$. $\mathrm{sp}$. (Fig. 2) have been recovered from samples K2.0, K2.9 $\alpha$ and $\mathrm{K} 2.10$ and are the most biostratigraphically useful species in the assemblage.

Few of the taxa originally described by Cramer et al. (1974) have been recognized in the material we have studied. Based on their illustrations, the Ancyrochitina species that they identified were left in open nomenclature in our study; Conochitina oelandica, as illustrated by Cramer et al. (1974, fig. 7), probably represents a different species: $C$. oelandica has been placed in synonymy with Eisenackitina rhenana by Nõlvak \& Grahn (1993), which is an index species for the lowest Sandbian (Nõlvak \& Grahn, 1993; Vandenbroucke, 2004); the specimen illustrated by Cramer et al. (1974) does not have the typical S-shaped flank of E. rhenana (cf. Vandenbroucke, 2004); in contrast, it is similar in general shape to the bursachitinids, such as those recognized by Verniers \& Vandenbroucke (2006, fig 4G) in the Late Ordovician of Dob's Linn (Scotland).

\section{DATING AND CORRELATION OF THE SOOM SHALE}

In the North Gondwanan realm, the strata straddling the Ordovician-Silurian (O/S) boundary host a suite of Spinachitina species, enabling precise subdivision of this interval. A short overview is given in Figure 2, with special attention to the species collected from the Soom Shale Member. Although the taxonomic history of these species is complex (Fig. 2), three distinct morphotypes can be distinguished: (i) a compact, rather short Spinachitina with well-differentiated spines (Spinachitina oulebsiri); (ii) a rather compact Spinachitina with poorly differentiated spines (Spinachitina verniersi n. sp.); and (iii) an elongated Spinachitina with well-differentiated spines (Spinachitina fragilis long forms). The first two were recovered from the Soom Shale Member.

During the last couple of decades, Spinachitina fragilis has been considered as being indicative of the lowermost Silurian, and was elected as the index species for the lowest Silurian biozone in 'the global chitinozoan biozonation for the Silurian' by Verniers et al. (1995, also see references therein). In the Gondwanan realm, it therefore immediately succeeded the uppermost Ordovician biozone, the Spinachitina oulebsiri Biozone, defined by the range of its index fossil (Webby et al., 2004). Recently, Butcher (2009) has synonymized Spinachitina fragilis and Spinachitina oulebsiri. In this scenario, S. fragilis, the senior synonym, and its eponymous biozone would range from the uppermost Ordovician to the lower Silurian, and would span the range of the former $S$. oulebsiri and $S$. fragilis Biozones. This would also be, as Butcher (2009) pointed out, in good agreement with earlier findings of Melchin \& Holmden (2006), who suggested that placing the base of the $S$. fragilis Biozone below the $\mathrm{O} / \mathrm{S}$ boundary would facilitate intercontinental correlation of sections that yielded both chitinozoan and $\delta^{13} \mathrm{C}$ data. 
However, we see merit in a continued split between the two Spinachitina species. We are able to see subtle differences between the two species (see systematic section) and prefer to await a direct comparison between the vast N. Gondwana assemblages and a full assemblage of the Estonian S. fragilis material that includes the holotype before assessing the possible synonymy of $S$. oulebsiri and $S$. fragilis. The Estonian material is from a drill core, and a large chitinozoan collection may be unavailable, but studies planned by FP may throw more light on this question.

Spinachitina oulebsiri has been reported from post-glacial deposits in the NE Algerian Sahara (Paris et al., 2000) and also occurs in the Bou Ingarf section in the Moroccan Anti-Atlas (Bourahrouh et al., 2004, p. 27; Elaouad-Debbaj, 1984: 61, identified as Spinachitina bulmani; Paris unpublished data); in both sections, Spinachitina oulebsiri co-occurs with species of the preceding biozone, the Tanuchitina elongata Biozone. The latter is usually considered typical of the glacial episode in the Hirnantian, and is often found in the Hirnantian glacial diamictites (Paris et al., 2000; Bourahrouh et al., 2004). Higher up in the stratigraphy, Spinachitina oulebsiri occurs without the $T$. elongata fauna, e.g. in the Nseirat section in Mauritania (Paris unpublished data; Paris et al., 1998, in assemblage 1), and in the MKSR-1 core in Saudi Arabia, where it was originally identified as $S$. aff. $S$. fragilis by Paris et al. (1995).

Long forms of Spinachitina fragilis ( $300 \mu \mathrm{m}$ and more), often referred to as true $S$. fragilis in previous publications dealing with N. Gondwana sections (e.g. Paris et al., 1995, 1998, 2000), appear still higher in the stratigraphy as a further evolved member of the Spinachitina fragilis lineage (including S. oulebsiri, S. verniersi and S. fragilis; see Paris et al., 2000 and Fig. 3). It remains to be seen whether these specimens fall within the same assemblage as the holotype, or whether they should be separated as a new species (Paris, work in progress). These forms have not been recovered from the Soom Shale and will not be dealt with in detail here.

We can calibrate these ranges with the graptolite biostratigraphy in the Nseirat section (Mauritania): Spinachitina oulebsiri (identified within local Nseirat assemblage 1 as Spinachitina sp. off. bulmani) and long Spinachitina forms (identified as Spinachitina fragilis within local assemblage 2 and higher) have been observed from separate levels from the $N$. persculptus graptolite Biozone (Paris unpublished data; Paris et al., 1998; Underwood et al., 1998) in the Nseirat section, and the long forms continue upwards into the Silurian. However, Loydell (2007) rejected some of Underwood et al.'s (1998) key graptolite identifications. This is crucial, as prior to Loydell's revision, the Nseirat section was one of the few sections that allowed calibration of the occurrence of $S$. oulebsiri with Hirnantian graptolites and, therefore, one of the few sections that independently demonstrated the latest Ordovician age of this chitinozoan. Strata at Nseirat dominated by Cyathochitina gr. caputoi, but also yielding other chitinozoans including $S$. oulebsiri, contain graptolites reported by Underwood et al. (1998) as Normalograptus cf. extraordinarius. Legrand (in press), however, included these specimens in the synonymy list of a new species of Normalograptus, which he assigned either to the $N$. persculptus Biozone or more probably to the lowermost part of the ascensus-acuminatus Biozone (Legrand, 2006). In that case, the base of the Nseirat section (i.e. the part of it sampled for chitinozoans) is very close to the base of the Rhuddanian.

Spinachitina oulebsiri (originally identified as $S$. aff. S. fragilis) and long forms of $S$. fragilis (identified as $S$. fragilis) co-occur immediately below acuminatus Biozone graptolites in the MKSR-1 core in Saudi Arabia (Paris et al., 1995). The latter co-occur with C. caputoi (Paris et al., 1995; see below).

A second species of Spinachitina, here named Spinachitina verniersi n. sp., has been recovered from the Soom Shale Member. This form has also been found (under various names, see below in the systematics section) in the M'Kratta Formation of the NE Algerian Sahara (Paris et al., 2000), the Hirnantian lower Second Bani Formation of the central Anti-Atlas of Morocco (Bourahrouh et al., 2004), the Hirnantian Ashgill Shales Formation in the type area of the British Ashgill Series in Northern England (Vandenbroucke et al., 2005; Vandenbroucke, 2008), and in the lower 'hot shale' (Mudawwara Shale Formation) of Rhuddanian age in Jordan, where it co-occurs with $S$. fragilis in the upper ascensus-acuminatus graptolite biozonal interval (Butcher, 2009). Spinachitina verniersi n. sp. is also reported from the Moussegouda Shale in Chad (Paris, unpublished data). The latter is sedimentologically very similar to the Soom Shale, and immediately overlies diamictites which yielded Armoricochitina nigerica, one of the key elements of the T. elongata Biozone fauna.

Clearly, the taxonomy of Spinachitina around the Ordovician-Silurian boundary is in urgent need of revision. This is not within the scope of this paper as it necessitates a world-wide investigation of the sections and taxa. Nevertheless, it is certainly possible to use the Spinachitina lineage to date the Soom Shale Member accurately: the presence of $S$. oulebsiri places the samples in the Hirnantian or Rhuddanian; the Soom Shale assemblage has relatively short Spinachitina species $(S$. oulebsiri and $S$. verniersi n. sp.) and lacks (with very few exceptions) the longer forms, which in other places appear more or less at the O/S boundary. In addition, it lacks any elements of the Tanuchitina elongata fauna, which places the samples high in the Hirnantian. Furthermore, $S$. verniersi n. sp. has been recorded only from Hirnantian sections in other localities, apart from the one Rhuddanian locality in Jordan (Butcher, 2009). Taken together, this evidence indicates that the Soom Shale Member can probably be dated to the late Hirnantian. However, given the rather loose constraints on the FAD of the longer forms of $S$. fragilis vis-à-vis the graptolite biozonation in some of the key sections (e.g. Nseirat, see Loydell, 2007; Underwood et al., 1998), an earliest Rhuddanian age for the samples from the Soom Shale Member cannot be excluded. Nevertheless, the interval remains tightly constrained in time to the latest (post-glacial) Hirnantian and the earliest Rhuddanian.

The apparent dominance of the $C$. caputoi group in the higher samples (Table 1) is of interest as the development and proliferation of this Cyathochitina species usually fits well with the base of the Silurian. This can be observed in various localities, such as in Bohemia and Brittany (Bourahrouh, unpublished data), in the MKSR-1 core (see above; Paris et al., 1995), and in the Nseirat section if one follows the graptolite re-assignment of Legrand (in press).

Ancyrochitina species that have been recorded from the Soom Shale Member, Ancyrochitina sp. A and Ancyrochitina 


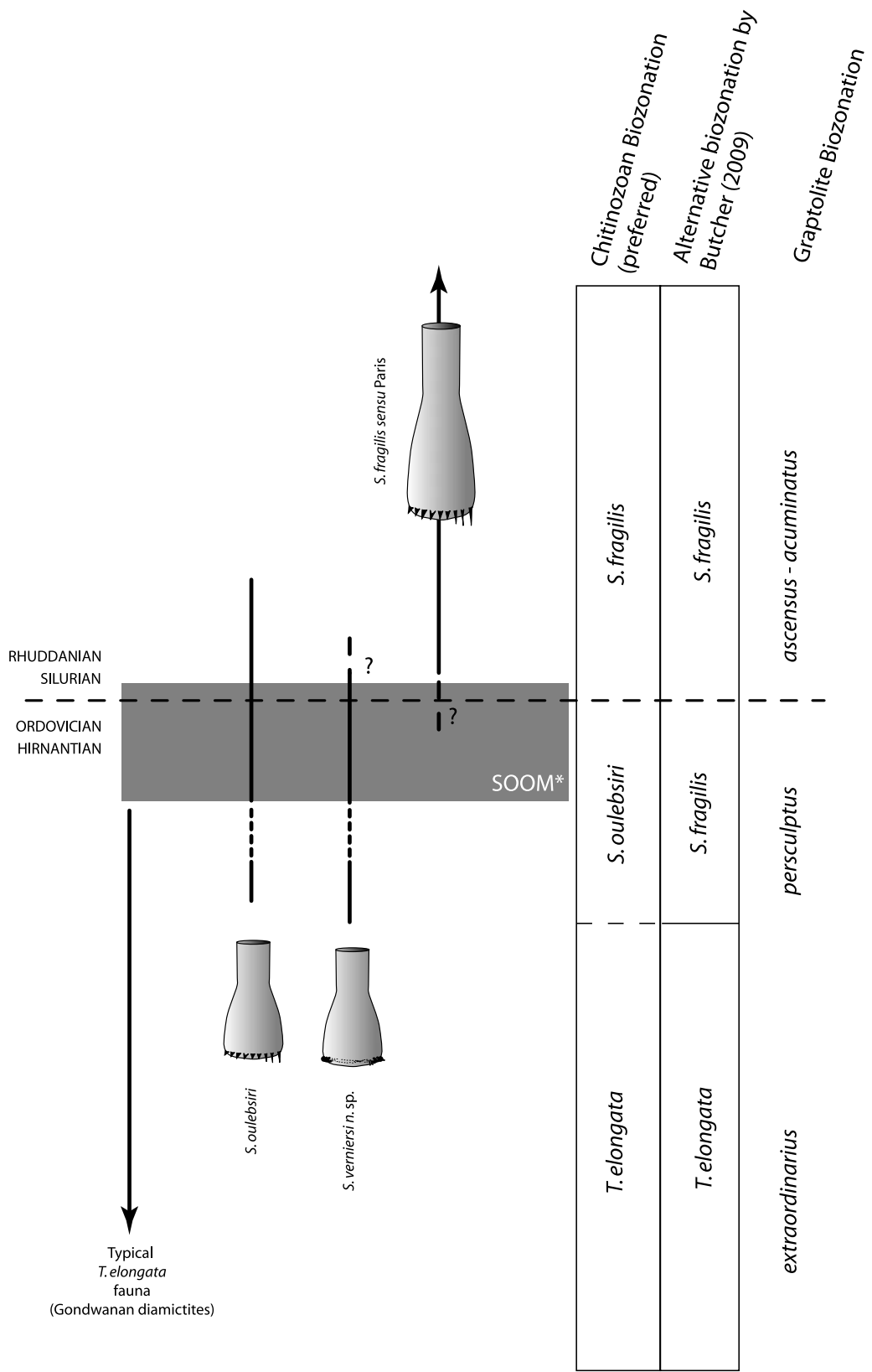

Fig. 3. A Gondwanan model that shows the stratigraphical ranges of the three key Spinachitina species discussed in the text. The Tanuchitina elongata fauna is typical of the glacial deposits in the Hirnantian; Spinachitina oulebsiri and Spinachitina verniersi n. sp. appear in the post-glacial melting phase/transgression, which occupies the transitional interval between the Ordovician and Silurian. Spinachitina fragilis is typical of the early Silurian. The time of deposition of the Soom Shale Member is within the grey area labelled SOOM*. A more precise calibration of these chitinozoan ranges versus the graptolite stratigraphy is work in progress (detailed in the text).

sp. C, are respectively close to Ancyrochitina ellisbayensis and Ancyrochitina cf. corniculans, which have both been reported from Ordovician/Silurian boundary strata of Anticosti Island, Canada (Soufiane \& Achab, 2000). This corroborates the suggested Hirnantian-Rhuddanian age for the Soom Shale.

Cramer et al. (1974, fig. 9) illustrated a large specimen that could well be a specimen of Armoricochitina nigerica, a typical Katian-Hirnantian species, which ranges below and into the lower part of the oulebsiri Biozone. The same authors also listed
Desmochitina minor, which normally does not range above the base of the Silurian.

\section{SYSTEMATIC DESCRIPTIONS OF SELECTED TAXA}

Chitinozoan dimensions are given in micrometres, using three dash-separated values, indicating the minimum, the average and the maximum value of the parameter. The following abbreviations, from Paris (1981), are used: L, total length; Dp, maximum chamber diameter; Dc, diameter of oral tube; $n$ is the number of measured specimens. 
Incertae sedis Group Chitinozoa Eisenack, 1931 Order Prosomatifera Eisenack, 1972

Family Conochitinidae Eisenack, 1931 emend. Paris, 1981 Subfamily Spinachitininae Paris, 1981 Genus Spinachitina Schallreuter, 1963

Spinachitina oulebsiri Paris et al., 2000

$$
\text { (P1. 1, figs 1-12) }
$$

.pars 1984 Spinachitina bulmani (Jansonius); Elaouad-Debbaj: 61, pl. 3, figs 6-8, 10, 12; non pl. 2, figs 7-8.

v. pars 1995 Spinachitina fragilis (Nestor); Paris et al:: 77, non pl. 1, fig. 1. [figured specimen = long form: $340 \mu \mathrm{m}$ long; but some other specimens of the assemblage are $S$. oulebsiri]

v. 1995 Spinachitina aff. S. fragilis (Nestor); Paris et al.: 77 [listed only].

v. 1998 Spinachitina sp. aff. fragilis (Nestor); Paris et al. [listed only].

*v. 2000 Spinachitina oulebsiri Paris et al.: 99, pl. 1, figs 2, 3.

?pars v 2008 Spinachitina sp. 5 Vandenbroucke: pl. 29, fig. 7; non pl. 21, figs 8, 11, 12 .

?pars v 2008 Spinachitina bulmani (Jansonius); Vandenbroucke: pl. 26, fig. 3; non pl. 5, fig. 14; non pl. 23, fig. 17.

?v 2008 Spinachitina ?fragilis (Nestor); Vandenbroucke: pl. 26, fig. 9 [single specimen: identification uncertain].

?v 2008 Spinachitina ?fragilis (Nestor); Vandenbroucke et al. [listed only $=$ identical to previous record].

?v 2008 Spinachitina sp. 5 Vandenbroucke et al. [listed only].

?pars v 2008 Spinachitina bulmani (Jansonius); Vandenbroucke et al. [listed only].

Diagnosis. 'Spinachitina species with a short (150-250 $\mu \mathrm{m})$ conical thin-walled vesicle; the margin bears a crown of about 20 short (less than $8 \mu \mathrm{m}$ ) conical and simple spines' (Paris et al., 2000, p. 99).

Material. 105 specimens from samples K2.0 and K2.10

Age. Latest Ordovician (late Hirnantian) to earliest Silurian (early Rhuddanian). If our suggested synonymy (see list above) of Spinachitina oulebsiri with Spinachitina sp. 5 from the Hirnant Limestone Member of Hirnantian age (Vandenbroucke et al. 2008 ) is correct, this will be important for the age attribution of the species.

Description. See Paris et al. (2000). Our material consists of cylindro-conical specimens with a relatively short neck and a gentle flexure. The neck is straight to slightly flaring and bears a fringe of small spines around the aperture. The vesicle wall is smooth to delicately granular. The basal margin, frequently folded during flattening, bears a crown of about 20, triangular (to rather cylindro-conical with broadened bases), wellseparated spines. Transitional specimens to Spinachitina verniersi n. sp. have been included herein.

Dimensions. L: $105-163-270 \mu \mathrm{m}$; Dp: 55-72-100 $\mu \mathrm{m}$; Dc: 25-42-60 $\mu \mathrm{m}(n=46)$. See Figure 4.

Remarks. Our specimens are typical of the species Spinachitina oulebsiri. We chose not to follow Butcher's (2009) synonymy of
S. oulebsiri and Spinachitina fragilis and we refer to that paper for a discussion of $S$. fragilis. Based solely on the original descriptions of both species by Nestor (1994) and Paris et al. (2000), it is difficult indeed to distinguish the two species and the differences are subtle (and thus easier to observe when presented with a large assemblage): $S$. oulebsiri has conical (triangular when flattened) spines, whereas $S$. fragilis (or least its holotype) has more cylindrical spines (although the morphological variability may be greater than indicated by the limited amount of material that is available from Estonia). Another difference concerns the width of the chamber vis-à-vis the vesicle length: the holotype of $S$. fragilis is more slender than specimens assigned to $S$. oulebsiri here, which have a more conical chamber and a stouter general appearance (especially noticeable in flattened specimens).

In addition, we are uncertain regarding the inclusion in Butcher's (2009) synonymy of $S$. fragilis of the larger specimens originally attributed to S. fragilis (e.g. by Paris et al., 1995); these probably represent a new species and will need to be renamed in the future. These larger Spinachitina forms have been provisionally referred to as $S$. fragilis 'long forms' in this text. No large 'forms' of $S$. fragilis have been found in the Soom Shale; we interpret this to be a genuine stratigraphic signal.

\section{Spinachitina verniersi $\mathrm{n}$. $\mathrm{sp}$.}

$$
\text { (P1. 2, figs 1-12) }
$$

v. 2000 Spinachitina sp. aff. oulebsiri Paris et al.: pl. 1, figs 1, 4. v. 2004 Spinachitina sp. aff. oulebsiri Bourahrouh et al.: pl. 4, figs 6,10 .

?2005 Spinachitina sp. aff oulebsiri Hints et al.: fig. 4 [listed only]. v. 2005 Spinachitina sp. 3 Vandenbroucke et al. [listed only].

pars v. 2008 Spinachitina sp. 5 Vandenbroucke: pl. 21, figs (8?,) 11, 12; ?non pl. 29, fig. 7.

v. 2008 Spinachitina sp. off. oulebsiri Paris et al.; Vandenbroucke: pl. 26, figs 5-8.

v. 2008 Spinachitina sp. off. oulebsiri Paris et al.; Vandenbroucke et al. [listed only].

.pars 2009 Spinachitina fragilis (Nestor); Butcher: pl. 3, figs 6-10.

Derivation of name. In honour of Prof. Jacques Verniers, who supervised TVDB's earlier work (MSc \& $\mathrm{PhD}$ ) and who is a significant Silurian chitinozoan worker.

Diagnosis. Small, cylindro-conical Spinachitina species with a crown of c. 40 numerous, closely spaced, hardly differentiated to undifferentiated spines and/or scars at the basal margin; the latter often resembles a row of colons $(: \ldots::)$ that are the remains of hollow short spines that were either bi-rooted or had a vertically stretched insertion.

Holotype. The specimen (IGR 70013) originally identified as Spinachitina sp. aff. oulebsiri (by Paris et al., 2000), figured in Paris et al. (2000, pl. 1, fig. 4), from the upper member of the M'Kratta Formation in the NE Algerian Sahara, well N1-2, core 29, depth $2655.30 \mathrm{~m}$. Collections of the Geological Institute of Rennes University, France, IGR 70013 (L52). 

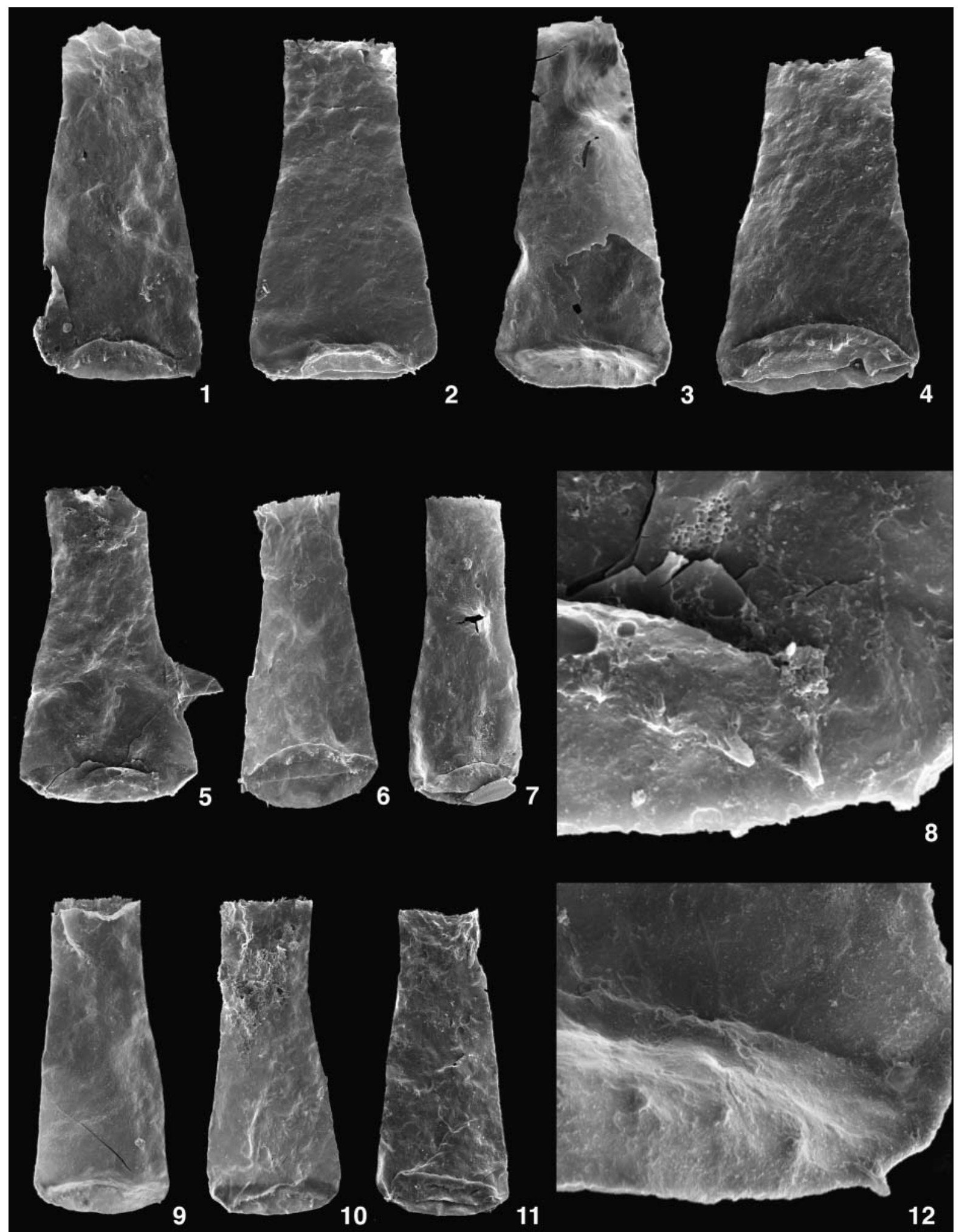

Explanation of Plate 1.

figs 1-12. Spinachitina oulebsiri: 1, $160 \times 70 \times 45$, specimen C2044, sample K2.0; 2, $130 \times 70 \times 40$, specimen C2045, sample K2.0; 3, 195 $\times 90 \times 45$, specimen C2046, sample K2.0; 4, $120 \times 75 \times 45$, specimen C2047, sample K2.0; 5, $150 \times 78 \times 42$, specimen C2048, sample K2.0; 6, $140 \times 60 \times 35$, specimen C2049, sample K2.0; 7, $180 \times 65 \times 45$, specimen C2050, sample K2.0; 8, close up of figure 5; 9, $140 \times 60 \times 35$, specimen C2051, sample K2.0; 10, $150 \times 60 \times 40$, specimen C2052, sample K2.0; 11, $140 \times 60 \times 35$, specimen C2053, sample K2.0; 12, close up of figure 3 . All measurements in $\mu$ m $(\mathrm{L} \times \mathrm{Dp} \times \mathrm{Dc})$. Abbreviations, following Paris (1981): L, total length; Dp, chamber diameter; Dc, diameter of oral tube. 


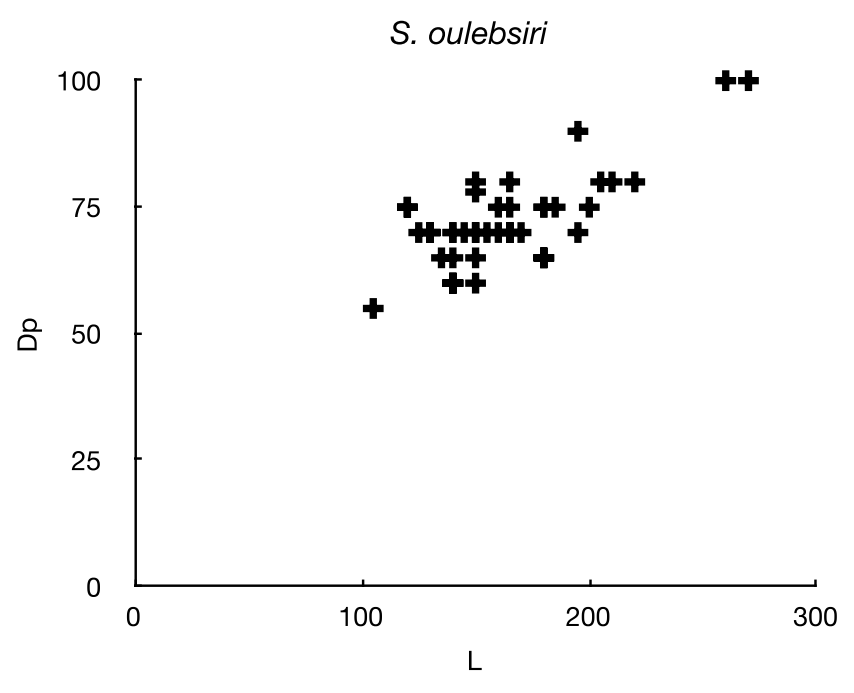

S. verniersi n. sp.

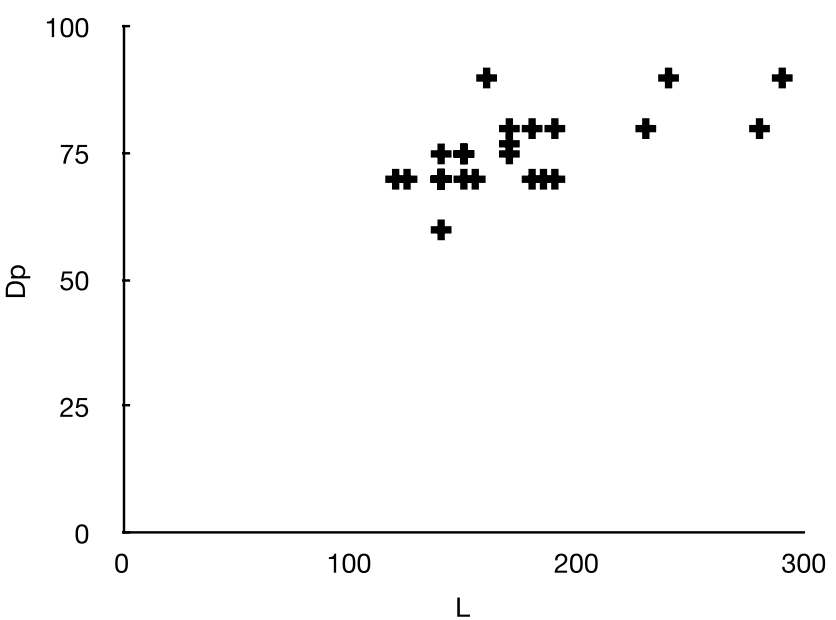

Fig. 4. Length-width diagrams of the specimens of Spinachitina oulebsiri and Spinachitina verniersi $\mathrm{n}$. sp. from the Soom Shale Member. Abbreviations, following Paris (1981): L, total length; Dp, chamber diameter.

Paratype. Paris et al. (2000, pl. 1, fig. 1, IGR 70011); well Nl-2, core 29, depth $2656.00 \mathrm{~m}$; collections of the Geological Institute of Rennes University, France, IGR 70011 (O40/3).

Material. 58 specimens from samples K.2.0 and K.2.9 $\alpha$. Stored at the Council for Geoscience, Bellville, South Africa, collection numbers C2044-2086.

Age. Latest Ordovician (late Hirnantian). Sporadically observed in earliest Silurian strata (early Rhuddanian, Butcher, 2009).

Description. The general vesicle shape is the same as that of Spinachitina oulebsiri. The material consists of cylindro-conical specimens with a gentle to somewhat more pronounced flexure. The neck is slightly flaring and bears a fringe of small spines around the aperture. The base bears a series of poorly separated spines and scars of spines; the latter often occur in two closely spaced, parallel rows (Pl. 2, fig. 12), as witnesses of broken, bi-rooted spines, or of hollow short spines with stretched bases (insertion on the margin) that were broadly parallel to the longitudinal axis of the vesicle. The bi-rooted spines have varied morphologies and, for instance, can be arch-shaped or lambdashaped.

Dimensions. L: $120-173-290 \mu \mathrm{m}$; Dp: $60-75-90 \mu \mathrm{m}$; Dc: $30-45-60 \mu \mathrm{m}(n=25)$. See Figure 4.

Stratigraphic range/occurrence. To date, known from the Soom Shale Member of the Cedarberg Formation in South Africa (this study), the M'Kratta Formation in the NE Algerian Sahara (Paris et al., 2000), the lower Second Bani Formation in the central Anti-Atlas of Morocco (Bourahrouh et al., 2004), the Moussegouda post-glacial shale in northern Chad (Paris, pers. obs.), the Ashgill Shales Formation in Northern England (Vandenbroucke et al., 2005), the Cwmere Formation and the Cerig Gwynion Grit facies of the Caban Conglomerate Formation in central Wales (Vandenbroucke et al., 2008) and the Mudawwara Shale Formation in Jordan (Butcher, 2009).

Remarks. Although we may become convinced of Butcher's (2009) synonymy of Spinachitina oulebsiri with S. fragilis, we do not follow his attribution of $S$. sp. aff. oulebsiri (sensu Paris et al., 2000) to the same species. We have erected a new species, Spinachitina verniersi $\mathrm{n}$. sp. for those specimens with a crown of very numerous and poorly separated spines. Although a lot of transitional forms between $S$. oulebsiri and $S$. verniersi $\mathrm{n}$. sp. can be observed (with a growing number of spines, and/or different degrees of spine separation), the two end-members are considered distinctive enough to support the split into two species. Until now, no specimens have been found that show the characteristics of both species on a single specimen. In the Soom Shale samples, doubtful (intermediate) specimens have in most cases been attributed to $S$. oulebsiri (Pl. 1, fig. 10). Vandenbroucke (2008) reported the species from the UK, as Spinachitina sp. 5 (pars, excluding the specimen figured on his pl. 29, fig. 7, which seems to be closer to $S$. oulebsiri).

Family Lagenochitinidae Eisenack, 1931, emend. Paris, 1981 Subfamily Ancyrochitininae Paris, 1981

Genus Ancyrochitina Eisenack, 1955

$$
\begin{gathered}
\text { Ancyrochitina sp. A } \\
\text { (P1. 3, figs 1-7) }
\end{gathered}
$$

Description. Compact, wide Ancyrochitina species with a very short, flaring neck, spiny ornamentation on the test and multi-branched appendices.

Dimensions. L: $90-100-115 \mu \mathrm{m}$; Dp: $65-75-85 \mu \mathrm{m}$; Dc: $25-31-40$ $\mu \mathrm{m}(n=32)$.

Remarks. The species is morphologically close to Ancyrochitina ellisbayensis, which has been reported from Ordovician/Silurian boundary strata of Anticosti Island, Canada (Soufiane \& 

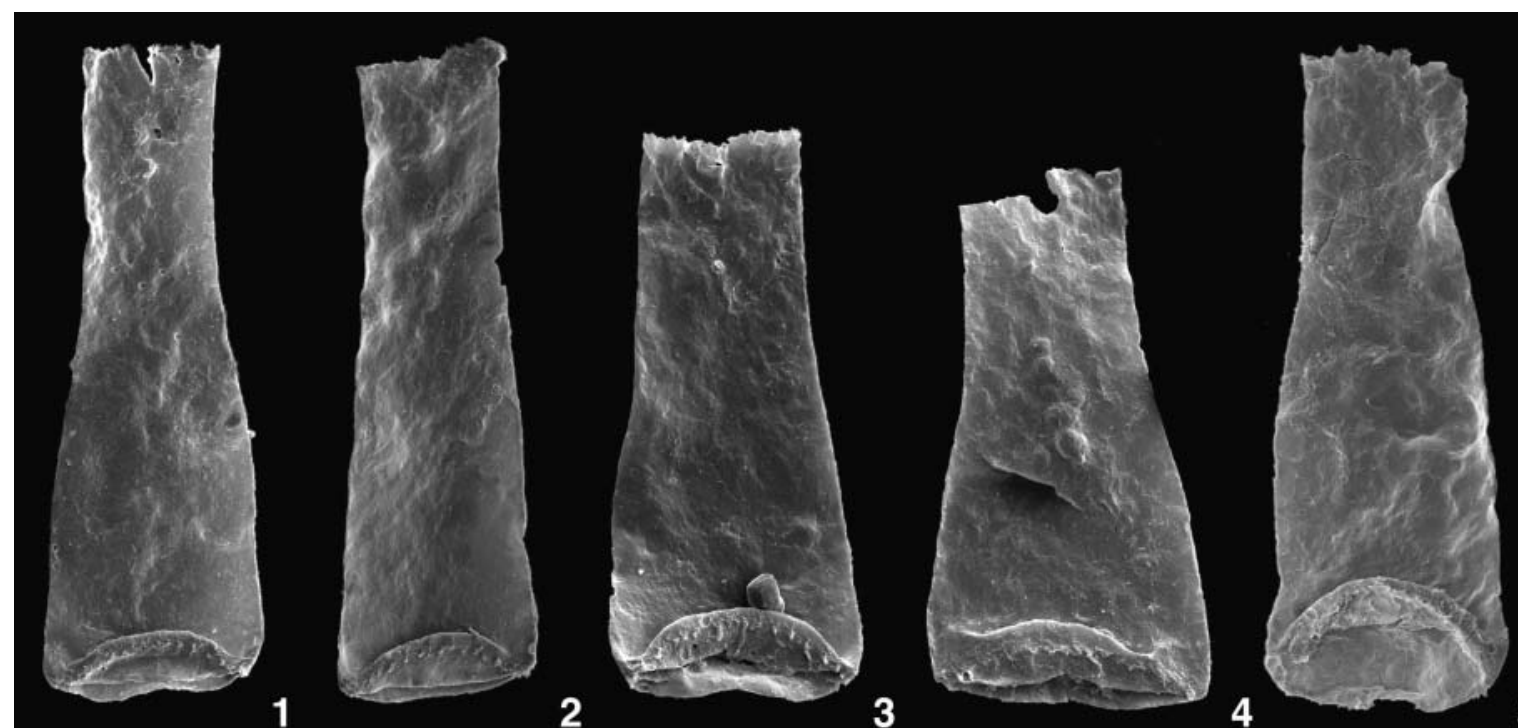

5
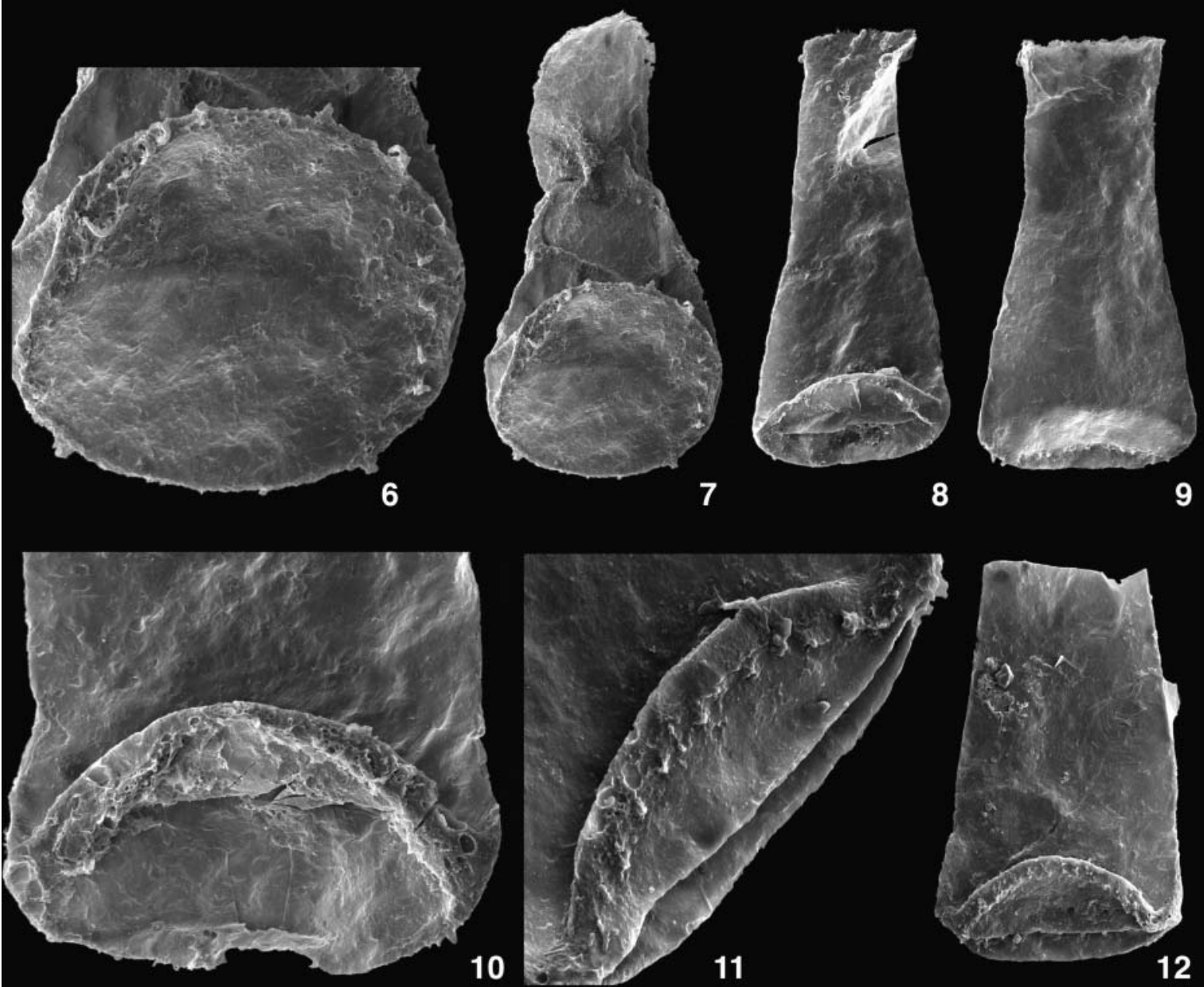

Explanation of Plate 2.

figs 1-12. Spinachitina verniersi $\mathrm{n}$. sp: $\mathbf{1}, 230 \times 80 \times 50$, specimen C2054, sample K2.0; 2, $290 \times 90 \times 60$, specimen C2055, sample K2.0; 3, 170 $\times 75 \times 49$, specimen C2056, sample K2.0; 4, $140 \times 70 \times 43$, specimen C2057, sample K2.0; 5, $240 \times 90 \times 55$, specimen C2058, sample K2.0; 6, close up of figure 7; 7, $140 \times 70 \times 35$, specimen C2059, sample K2.0; 8, $170 \times 77 \times 35$, specimen 2060, sample K2.0; 9, $150 \times 75 \times 45$, specimen C2061, sample K2.0; 10, close up of figure 5 ; 11, close up of figure $12 ; \mathbf{1 2}, 140 \times 85$, specimen C2062, sample K2.0. All measurements in $\mu \mathrm{m}(\mathrm{L} \times \mathrm{Dp}$ or $\mathrm{L} \times \mathrm{Dp} \times \mathrm{Dc})$. See Plate 1 for abbreviations. 

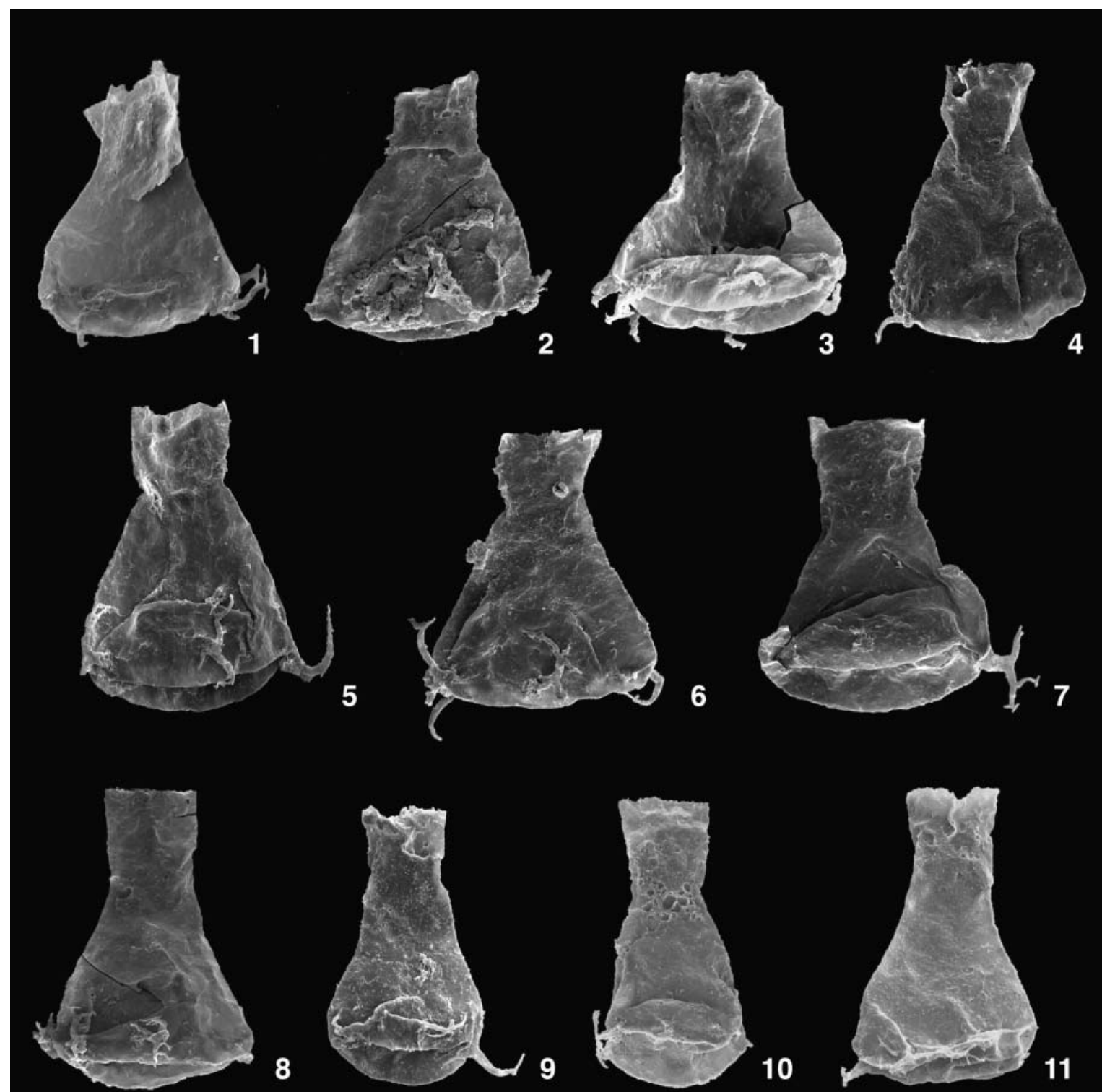

8
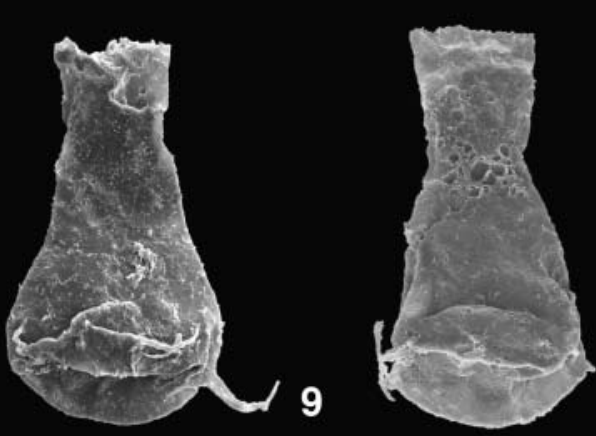

10
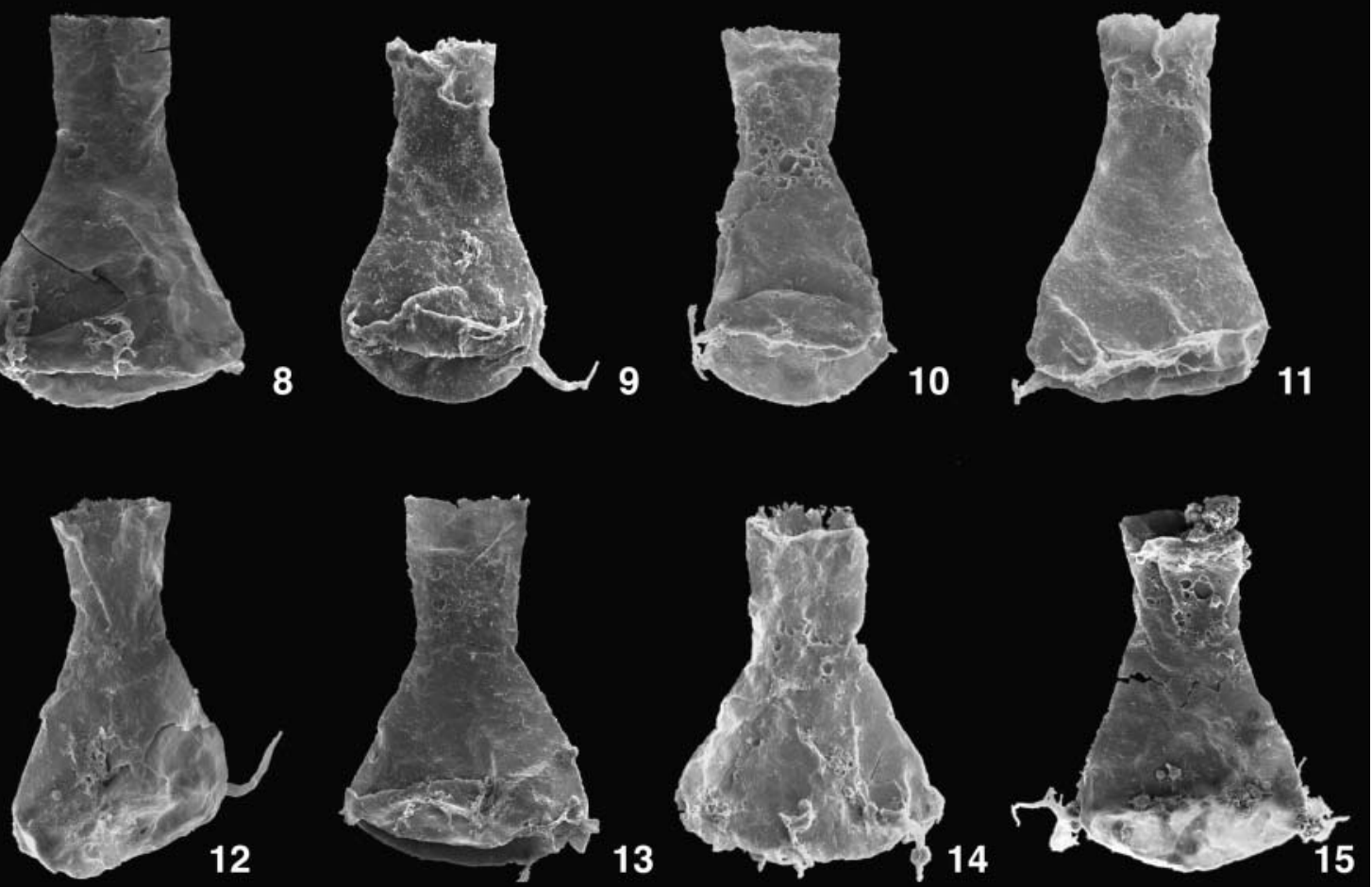

Explanation of Plate 3.

figs 1-7. Ancyrochitina sp. A: 1, $110 \times 80 \times 30$, specimen C2063, sample K2.0; 2, $95 \times 80 \times 30$, specimen C2064, sample K2.0; 3, $90 \times 80 \times 35$, specimen C2065, sample K2.0; 4, $105 \times 70 \times 25$, specimen C2066, sample K2.0; 5, $105 \times 70 \times 25$, specimen C2067, sample K2.0; 6 , $105 \times 85 \times 28$, specimen C2068, sample K2.0; 7, $100 \times 75 \times 30$, specimen C2069, sample K2.0. figs 8-15. Ancyrochitina sp. B: 8, $110 \times 70 \times 30$, specimen C2070, sample K2.0; 9, $130 \times 70 \times 35$, specimen C2071, sample K2.3; 10, $140 \times 65 \times 35$, specimen C2072, sample K2.3; 11, $130 \times 80 \times 35$, specimen C2073, sample K2.3; 12, $110 \times 70 \times 25$, specimen C2074, sample K2.0; 13, $120 \times 80 \times 30$, specimen C2075, sample K2.0; 14, $105 \times 80 \times 30$, specimen C2076, sample K2.0; 15, $110 \times 70 \times 30$, specimen C2077, sample K2.0. All measurements in $\mu \mathrm{m}(\mathrm{L} \times \mathrm{Dp} \times \mathrm{Dc})$. See Plate 1 for abbreviations. 


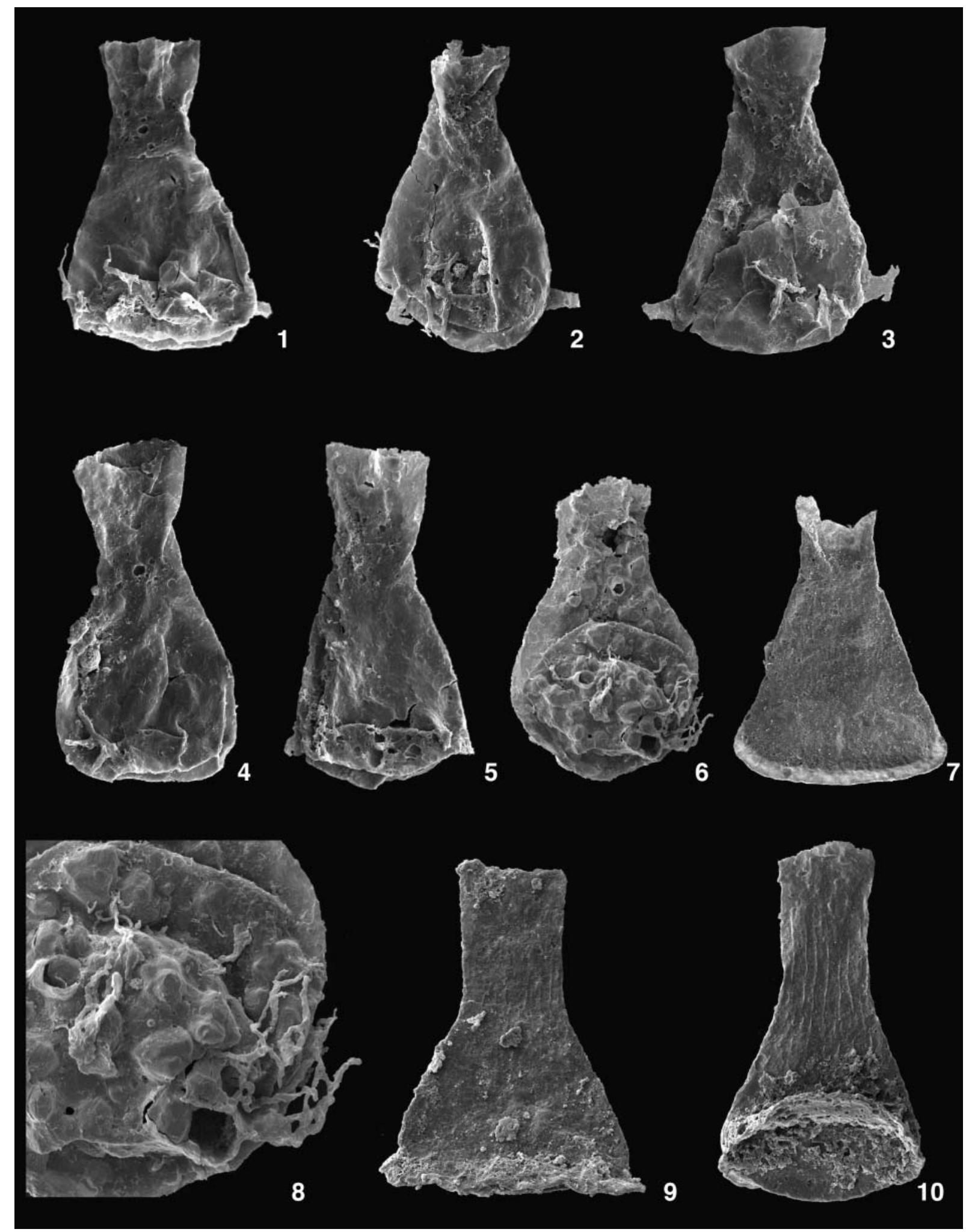

\section{Explanation of Plate 4.}

figs 1-5. Ancyrochitina sp. C: $\mathbf{1}, 115 \times 70 \times 25$, specimen C2078, sample K2.0; 2, $120 \times 70 \times 25$, specimen C2079, sample K2.0; 3, $110 \times 65 \times 25$, specimen C2080, sample K2.0; 4, $130 \times 65 \times 30$, specimen C2081, sample K2.0; 5, $125 \times 70 \times 28$, specimen C2082, sample K2.0. figs 6, 8. Angochitina sp.: 6, $100 \times 65 \times 30$, specimen C2083, sample K2.0; 8, close up of figure 6. figs 7, 9-10. Cyathochitina caputoi group: 7, $230 \times 170 \times 60$, specimen C2084, sample K2.10; 9, $250 \times 180 \times 80$, specimen C2085, sample K2.10; 10, $310 \times 150 \times 60$, specimen C2086, sample K2.10. All measurements in $\mu$ m $(\mathrm{L} \times \mathrm{Dp} \times \mathrm{Dc})$. See Plate 1 for abbreviations. 
Achab, 2000) and Dob's Linn, Scotland (Verniers \& Vandenbroucke, 2006). The specimens from the Soom Shale Member have not been attributed to the species cited above, as they lack the bell-shaped (to hemispherical) chamber, which is typical of Ancyrochitina ellisbayensis. In addition, the specimens from South Africa are a little larger, and their ornamentation is slightly less well developed, although the latter may be due to their less than perfect preservation.

\section{Ancyrochitina sp. B \\ (Pl. 3, figs 8-15)}

Description. Small, cylindro-conical Ancyrochitina species with multi-branched appendices and a spiny test.

Dimensions. L: $90-113-170 \mu \mathrm{m} ; \mathrm{Dp}: \quad 60-74-120 \mu \mathrm{m}$; Dc: 20-30-55 $\mu \mathrm{m}(n=73)$.

Remarks. The species has a rather generalized appearance. Because of the imperfect preservation, it has been restricted to open nomenclature. This most probably is the same species that has been referred to Ancyrochitina merga by Cramer et al. (1974), and a specimen has also been reported by F.P. in a reprocessed sample from Cramer et al.'s (1974) collection, not included in Table 1 . Though possibly caused by the imperfect preservation of its specimens, Ancyrochitina sp. B does not display the characteristic shape of $A$. merga; the latter typically has very straight flanks and a well-rounded hemispherical base. Ancyrochitina sp. B differs from Ancyrochitina sp. A in having a longer, cylindrical neck, and a narrower chamber (compared to its total vesicle length) that is more conical (or ovoidal in some cases).

\section{Ancyrochitina sp. C \\ (Pl. 4, figs 1-5)}

Description. Ancyrochitina species with a flaring neck and conical to ovoid chamber. The test bears small spines and the base bears a couple of well-developed, rather thick appendices.

Dimensions. L: $110-126-160 \mu \mathrm{m}$; Dp: $60-70-80 \mu \mathrm{m}$; Dc: 25-29-40 $\mu \mathrm{m}(n=25)$.

Remarks. The species is morphologically very close to Ancyrochitina cf. corniculans sensu Soufiane \& Achab (2000), which has been reported from Ordovician/Silurian boundary strata of Anticosti Island, Canada (Soufiane \& Achab, 2000). It has not been formally synonymized with the latter species as the imperfect preservation hampers detailed comparison of the appendices between the two species. Species of ancyrochitinds are difficult to identify with certainty if the preservation of the specimens is not excellent, as is illustrated by the exclusively open nomenclature used in this study; specific distinction is often restricted to subtle differences in appendices, chamber morphology or ornament. Ancyrochitina sp. C has been separated from the other two Ancyrochitina species in this study based on its slightly larger dimensions, its conical-ovoid chamber (rather than strictly conical in sp. B) and the larger width of its appendices.

\section{CONCLUSIONS}

Despite taxonomic problems with the Spinachitina species, the Soom Shale fauna is interpreted as a typical ' $S$. oulebsiri Biozone assemblage'. In other localities, this assemblage is known to overlie Hirnantian glaciomarine diamictites that contain the classic elongata fauna and to underlie unequivocal Silurian (Rhuddanian) strata with $S$. fragilis chitinozoans and acuminatus zone graptolites. The cited taxonomic problems are not much more than a classic 'split or lump' discussion, and this revolves around whether or not to include $S$. oulebsiri in the diagnosis of $S$. fragilis. For this study, we have chosen the pragmatic approach of maintaining the split between the two morphotypes; if, in the future, some of the Soom Shale specimens need to be renamed, this will not change the latest Hirnantian to earliest Rhuddanian age assignment we suggest here for this unit. Although we cannot attribute this fauna without doubt to either the Ordovician or the Silurian, the proposed age represents a very narrow time slice (less than $1 \mathrm{Ma}$, conservatively counting: the interval probably represents much less time) straddling the system boundary.

\section{ACKNOWLEGEMENTS}

Stewart Molyneux (BGS) and Nick Miles (PetroStrat) carefully reviewed the manuscript. Mark Williams, Jan Zalasiewicz and Howard Armstrong are thanked for supporting TVDB's postdoc project, Anthony Butcher and Jacques Verniers for taxonomic discussion, Maarten Verreth (FWO Research Grant G.0271.05) for laboratory preparation and the Research Foundation - Flanders (FWO-Flanders) for financial support to TVDB. Collection of material was financed by NERC Research Grants GR9/957 and GR3/10177 (to RJA), by the National Geographic Society (Grant 6715-00 to RJA) and by the University of Leicester. The Council for Geoscience, South Africa, made the core samples available for study. The South African Heritage Resources Agency (SAHRA, National Heritage Authority) authorized the export permit that allowed us to study the fossil material in the UK. Helga Priewalder is thanked for the loan of the specimens reported by Cramer et al. This is a contribution to the IGCP 503.

\section{Manuscript received 21 July 2008 Manuscript accepted 22 February 2009}

\section{REFERENCES}

Aldridge, R.J., Gabbott, S.E. \& Theron, J.N. 2001. The Soom Shale. In: Briggs, D.E.G. \& Crowther, P.R. (Eds), Palaeobiology II. Blackwell Science, Oxford, 340-342.

Aldridge, R.J. \& Theron, J.N. 1993. Conodonts with preserved soft tissues from a new Ordovician Konservat Lagerstätte. Journal of Micropalaeontology, 12: 113-117.

Bergström, S.M., Finney, S.C., Chen, X, Golman, D. \& Leslie, S.A. 2006. Three new Ordovician global stage names. Lethaia, 39: 287-288.

Berry, W.B.N. \& Boucot, A.J. 1973. Glacio-eustatic control of late Ordovician-early Silurian platform sedimentation and faunal changes. Geological Society of America, Bulletin, 84: 275-284.

Bourahrouh, A., Paris, F. \& Elaouad-Debbaj, Z. 2004. Biostratigraphy, biodiversity and palaeoenvironments of the chitinozoans and associated palynomorphs from the Upper Ordovician of the Central AntiAtlas, Morocco. Review of Palaeobotany and Palynology, 130: 17-40.

Braddy, S.J., Aldridge, R.J., Gabbott, S.E. \& Theron, J.N. 1999. Lamellate book-gills in a late Ordovician eurypterid from the Soom 
Shale, South Africa: support for a eurypterid-scorpian clade. Lethaia, 32: 72-74.

Braddy, S.J., Aldridge, R.J. \& Theron, J.N. 1995. A new eurypterid from the Late Ordovician Table Mountain Group, South Africa. Palaeontology, 38: 563-581.

Butcher, A. 2009. Early Llandovery chitinozoans from Jordan. Palaeontology, in press.

Cocks, L.R.M. \& Fortey, R.A. 1986. New evidence on the South African Lower Palaeozoic: age and fossils reviewed. Geological Magazine, 123(4): 437-444.

Cramer, F.H., Rust, I.C. \& Cramer, M.D.C.R.D. 1974. Upper Ordovician chitinozoans from the Cedarberg Formation of South Africa. Preliminary note. Geologische Rundschau, 63: 340-345.

Eisenack, A. 1931. Neue Mikrofossilien des baltischen Silurs. I. Palaeontologische Zeitschrift, 13(1-4): 74-118.

Eisenack, A. 1955. Chitinozoen, Hystrichosphären und andere Mikrofossilien aus dem Beyrichia-Kalk. Senckenbergiana lethaea, 36(1-2): 157-188.

Eisenack, A. 1972. Beiträge zur Chitinozoen-Forschung. Palaeontographica A, 140: 117-130.

Elaouad-Debbaj, Z. 1984. Chitinozoaires ashgilliens de l'Anti-Atlas (Maroc). Géobios, 17(1): 45-68.

Gabbott, S.E. 1998. Taphonomy of the Ordovician Soom Shale Lagerstätte: an example of soft tissue preservation in clay minerals. Palaeontology: 41, 631-667.

Gabbott, S.E. 1999. Orthoconic cephalopods and associated fauna from the Late Ordovician Soom Shale Lagerstätte, South Africa. Palaeontology: 42, 123-148.

Gabbott, S.E., Aldridge, R.J. \& Theron, J.N. 1995. A giant conodont with preserved muscle tissue from the Upper Ordovician of South Africa. Nature: 374, 800-803.

Gabbott, S.E., Aldridge, R.J. \& Theron, J.N. 1998. Chitinozoan chains and cocoons from the Upper Ordovician Soom Shale Lagerstätte, South Africa: implications for affinity. Journal of the Geological Society, London, 155: 447-452.

Gabbott, S.E., Norry, M.J., Aldridge, R.J. \& Theron, J.N. 2001. Preservation of fossils in clay minerals; a unique example from the Upper Ordovician Soom Shale, South Africa. Proceedings of the Yorkshire Geological Society, 53: 237-244.

Gabbott, S.E., Siveter, D.J., Aldridge, R.J. \& Theron, J.N. 2003. The earliest myodocopes: ostracodes from the late Ordovician Soom Shale Lagerstätte of South Africa. Lethaia, 36: 151-160.

Gray, J., Theron, J.N. \& Boucot, A.J. 1986. Age of the Cedarberg Formation, South Africa and early land plant evolution. Geological Magazine, 123(4): 445-454.

Hiller, N. 1992. The Ordovician System in South Africa: A review. In: Webby, B.D. \& Laurie, J.R. (Eds), Global Perspectives on Ordovician Geology. Balkema, Rotterdam, 473-485.

Hints, L., Oraspõld, A. \& Nõlvak, J. 2005. The Pirgu Regional Stage (Upper Ordovician) in the East Baltic: lithostratigraphy, biozonation and correlation. Proceedings of the Estonian Academy of Sciences, Geology, 54(4): 225-259.

Legrand, P. in press. Analogie des séries stratigraphiques au sommet du 'Complexe terminal' ordovicien dans la région de l'Oued In Djerane (Tassili N'Ajjer oriental) et dans la région du Hodh (Mauritanie). In:

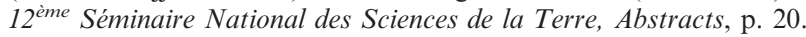

Legrand, P. 2009. Faunal specificity, endemism and paleobiogeography: the post-glacial (Hirnantian-early Rhuddanian) graptolite fauna of the north-African border of Gondwana: a case study. Bulletin de la Société Géologique de France.

Loydell, D.K. 2007. Graptolites from the Upper Ordovician and Lower Silurian of Jordan. Special Papers in Palaeontology, The Palaeontological Association 78, 68pp.

Melchin, M.J. \& Holmden, C. 2006. Carbon isotope chemostratigraphy in Arctic Canada: Sea-level forcing of carbonate platform weathering and implications for Hirnantian global correlation. Palaeogeography, Palaeoclimatology, Palaeoecology, 234: 186-200.

Nestor, V. 1994. Early Silurian chitinozoans of Estonia and North Latvia. Estonian Academy of Sciences, Estonian Academy Publishers, Tallinn, 163pp.
Nõlvak, J. \& Grahn, I. 1993. Ordovician chitinozoan zones from Baltoscandia. Review of Palaeobotany and Palynology, 79: 245-269.

Page, A.A., Zalasiewicz, J.A., Williams, M. \& Popov, L. 2007. Were transgressive black shales a negative feedback modulating glacioeustasy in the Early Palaeozoic Icehouse? In: Williams, M., Haywood, A.M., Gregory, F.J. \& Schmidt, D.N. (Eds), Deep time perspectives on climate change: marrying the signal from computer models \& biological proxies. Special Publications of The Micropalaeontological Society, Geological Society, London, 123-156.

Paris, F. 1981. Les chitinozoaires dans le Paléozoïque du sud-ouest de l'Europe (cadre géologique - étude systématique - biostratigraphie). Mémoire de la Société géologique et minéralogique de Bretagne 26, 496pp.

Paris, F., Bourahrouh, A. \& Le Hérissé, A. 2000. The effects of the final stages of the Late Ordovician glaciation on marine palynomorphs (chitinozoans, acritarchs, leiospheres) in well Nl-2 (NE Algerian Sahara). Review of Palaeobotany and Palynology, 113(1-3): 87-104.

Paris, F., Deynoux, M. \& Ghienne, J.-F. 1998. First record of chitinozoans from the Ordovician-Silurian boundary beds of Mauritania; palaeogeographic implications. Comptes Rendus de l'Académie des Sciences, Paris. Series II. Sciences de la Terre et des Planetes, 326: 499-504.

Paris, F., Verniers, J., Al-Hajri, S. \& Al-Tayyar, H. 1995. Biostratigraphy and palaeogeographic affinities of Early Silurian chitinozoans from central Saudi Arabia. Review of Palaeobotany and Palynology, 89: $75-90$.

Rong, Jia-yu, Chen, Xu \& Harper, D.A.T. 2002. The latest Ordovician Hirnantia Fauna (Brachiopoda) in time and space. Lethaia, 35: 231-249.

Rong, Jia-yu \& Harper, D.A.T. 1988. A Global synthesis of the latest Ordovician Hirnantian brachiopod faunas. Transactions of the Royal Society of Edinburgh: Earth Sciences, 79: 383-402.

Rust, I.C. 1981. Lower Palaeozoic rocks of southern Africa. In: Holland, C.H. (Ed.), Lower Palaeozoic of the Middle East, Eastern and Southern Africa, and Antarctica. John Wiley \& Sons Ltd, New York, 165-187.

Schallreuter, R. 1963. Neue Chitinozoen aus ordovizischen Geschieben und Bemerkungen zur Gattung Illichitina. Paläontologische Abhandlungen, 1(4): 391-405.

Soufiane, A. \& Achab, A. 2000. Chitinozoan zonation of the Late Ordovician and the Early Silurian of the Island of Anticosti, Québec, Canada. Review of Palaeobotany and Palynology, 109: 85-111.

Theron, J.N. \& Thamm, A.G. 1990. Stratigraphy and sedimentology of the Cape Supergroup in the Western Cape. In: Guidebook Geocongress 1990. Geological Society of South Africa, PR2, 1-64.

Underwood, C.J., Deynoux, M. \& Ghienne, J.-F. 1998. High palaeolatitude (Hodh, Mauritania) recovery of graptolite faunas after the Hirnantian (end Ordovician) extinction event. Palaeogeography, Palaeoclimatology, Palaeoecology, 142: 97-103.

Vandenbroucke, T. 2004. Chitinozoan biostratigraphy of the Upper Ordovician Fågelsång GSSP, Scania, southern Sweden. Review of Palaeobotany and Palynology, 130: 217-238.

Vandenbroucke, T.R.A. 2008. Upper Ordovician chitinozoans from the historical type area in the UK. Monograph of the Palaeontographical Society, London, no. 628, 161 for 2007, 113pp.

Vandenbroucke, T.R.A., Hennissen, J., Zalasiewicz, J.A. \& Verniers, J. 2008. New chitinozoans from the historical type area of the Hirnantian and additional key sections in the Wye Valley, Wales, UK. Geological Journal, 43: 397-414.

Vandenbroucke, T.R.A., Rickards, B. \& Verniers, J. 2005. Upper Ordovician Chitinozoan biostratigraphy from the type Ashgill Area (Cautley district) and the Pus Gill section (Dufton district, Cross Fell Inlier), Cumbria, Northern England. Geological Magazine, 142(6): 783-807.

Verniers, J., Nestor, V., Paris, F., Dufka, P., Sutherland, S.J.E. \& Van Grootel, G. 1995. A global Chitinozoa biozonation for the Silurian. Geological Magazine, 132: 651-666.

Verniers, J. \& Vandenbroucke, T.R.A. 2006. Chitinozoan biostratigraphy in the Dob's Linn Ordovician-Silurian GSSP, Southern Uplands, 
T. R. A. Vandenbroucke et al.

Scotland. Geologiska Föreningens i Stockholm Förhandlingar, 128: 195-202.

Webby, B.D., Cooper, R.A., Bergström, S.M. \& Paris, F. 2004. Chapter 2: Stratigraphic framework and time slices. In: Webby, B.D., Paris, F., Droser, M.L. \& Percival, I. (Eds), The Great Ordovician Biodiversification Event. Columbia University Press, New York, 41-47.
Whittle, R.J., Gabbott, S.E., Aldridge, R.J. \& Theron, J.N. 2007. The taphonomy and palaeoecology of a Late Ordovician caryocaridid from the Soom Shale Lagerstätte, South Africa. Palaeogeography, Palaeoclimatology, Palaeoecology, 251: 383-397. 